\title{
History as a Science
}

\author{
Boris Zemtsov \\ Bauman Moscow State Technical University \\ Moscow, Russia 105005 \\ E-mail: zemtsovbn@mail.ru
}

\author{
Tatiana Suzdaleva \\ Bauman Moscow State Technical University \\ Moscow, Russia 105005 \\ E-mail: syzdalev@list.ru
}

\begin{abstract}
The article is devoted to a relevant perspective of historical science: to historical regularities, specifics of historical knowledge, definition of a subject of historical science. Authors recognize what at the level of human acts of regularity it is difficult to reveal as each person is under the influence of unique factors and accidents, his acts can not coincide with historical tendencies. Equally, it belongs also to studying of history of mankind in general. Therefore the "world" or "general" history appears in the form of history of the certain countries or regions. Historical regularities are shown: first, at the level of regions (the certain countries or group of the countries having similar trajectories of development); secondly, at the level of the historical periods, stages; thirdly, at the level of social, political and economic institutes. Such approach leads to objective cognoscibility of historical process.
\end{abstract}

Keywords-history; historical regularities; science

\section{INTRODUCTION}

The need for continuous improvement of the scientific knowledge conceptual foundations causes a permanently ongoing discussion about history as a science. In the XXI century in the field of philosophy of history, a paradigm change occurred, namely, the transition from the narrative (descriptive) history to history as a science that sees the evidence problem solution in studying the purposeful human behavior. The aiming for systematicity, accuracy and evidence is inherent in the historians' ccommunity no less than in experts in other fields of science.

\section{THE CONCEPT OF SCIENCE}

On the one hand, an individual science "language" is unique and it is difficult to understand it for the representatives of other sciences. On the other hand, as the Hungarian philosopher Imre Lakatos remarked wittily: asking scientists what their science is means all the same as asking fish about the hydrodynamics laws [1]. Therefore, there exists a section of philosophy that studies the scientific knowledge concept, which determines the boundaries of scientific activity.

Such a complicated phenomenon as science can be studied from different positions:

- from the subject point of view, science is a system of knowledge about laws, properties and relations between certain objects [2]. And knowledge is expressed, as a rule, in an abstract form;
- from the social point of view, science is a certain type of people's activity, a social institution [3].

However, this classification is too general, wide and therefore simplified. Thus, if science is theoretical knowledge, based on the empirical data, then, for example, according to the physicist and Nobel Prize winner R. Feynman, "the mathematical science is not a science - in the sense that it does not belong to the natural sciences. After all, its measure of justice is by no means an experience" [4]. It seems that this statement is nothing more than a syllogism. However, in English-speaking countries, "we face with the paradox, that in relation to mathematics and logic, the word science is not used, with the general recognition that mathematics is almost the top of science" [1].

However, in the West, the definition of the content and concept of "science" depends not only on scientists, but also, strangely enough for the national researchers, on the companies ordering research. For example, in the United States in the inter-war period, it was the National Research Council, created in 1916 that in many ways determined the research subjects and the amounts of financing. At the international level, the Organization for Economic Cooperation and Development, established in 1948, played a significant role.

Scientists and representatives of institutions that finance Western science understand fundamental research as the original research aimed at the development of scientific knowledge, which does not have any commercial purposes, but may represent current or potential interest for the reporting company.

Applied research, in their understanding, is focused on the new scientific knowledge discovery and has specific commercial goals for products or processes.

Accordingly, developments are technical activities related to the non-standard problems [5].

Proceeding from this classification (of fundamental science, applied research and developments), history is a fundamental science. Fundamental science is research implying the studies of living and inanimate nature fundamental phenomena, resulting in theoretical knowledge emergence [6]. It is no coincidence that among the huge number of historical journals there are theoretical publications: «History and Theory», «Historical Method», «History Today», «Journal of 
Modern History», «Rethinking History», «American Historical Review», «History Workshop Journal».

However, many difficulties arise when trying to formulate a historical regularity.

\section{HistoricAl REGULARITIES MANIFESTATION} SPHERES

Historians' work aims at discovering historical regularities. However, some researchers initially abandon this goal. T.V. Panfilova, for example, believes that any attempts to reveal the universal are so detached from the concrete historical reality that as a result nothing particularly historical remains" [7]. She echoes O.V. Gerasimov: "... The fact that events are unique, and human actions motivation are individual, does not allow us to formulate the historical process direct regularities" [8]. These researchers' methodological error consists of mixing a particular historical phenomenon or event with a regularity that cannot exist otherwise than in an abstract form.

N.V. Starostenkov's assertion is also controversial: “... the experience accumulated by historical science will not allow us to speak about the validity of some certain scientific theory, which claims to be the only true one interpreting the past" [9]. In fact, there cannot exist any historical law common to all times and peoples, since historians deal with the most complex kind of matter — a society, which is extremely mobile in comparison with the atomic or molecular kind of matter.

The domestic academic institutions structure also pushes to doubt the existence of historical regularities. For example, in the Institute of World History of the Russian Academy of Sciences, only the "Department of Theoretical Studies" deals with the analysis of historical regularities that act on the scale of world history. At the same time, they study "the general laws of history, methodological and theoretical problems in historical sciences, modern models and concepts of the historical process" along with the other problems (the history of continents, regions and countries, power problems, society and personality, as well as Russia in world history, historical science integration and education).

\section{THE INSTITUTE OF RUSSIAN HISTORY OF THE}

\section{RUSSIAN ACADEMY OF SCIENCES CONSISTS OF 15 CENTERS}

For example, the Center of Early Russian History; the Center for studying the Russian History of the 19th century; the Center of modern Russian History studies, the Center of the peoples of Russia and inter-ethnic relations; the Center of Russian culture studies; the Center for History of Religion and Church, the Center of the military History of Russia; the Center for History of the peoples of Russia, the Center "Russia in international relations"; the Center for interethnic relations and History of the peoples of Russia; the Center for studies of the Recent History of Russia and Political Science; the Center or Economic History, the Center for the publication of resources on the History of Russia in the 20th century; the Center for the resource study of Russian History) etc. However, there is no department for general theory studies at the Institute.

In fact, the existing domestic academic institutions structure does not mean abandoning the search for historical regularities. Science is an activity to collect and systematize the objective knowledge about the world (nature) and society. In the natural sciences, this activity results in laws, and in the social sciences - in historical regularities. The difference between them is that we can define laws as the widest possible repeatability in time and space, but the historical regularities are less wide in time and space phenomena (due to the fact that they are more complex types of matter compared to all the others) [10].

According to A.N. Medushevsky, the research consists of the development of concepts that interpret the historical process at the evidence level; of harmonious and logically consistent concept creation; of criteria and limits determination of the findings evidence; of revealing the historical knowledge social functions [11].

Any natural scientist always marks his methods application limits. Only mathematicians have a luxury of absolute knowledge, and besides the theorems in mathematics there is a huge number of axioms i.e. assumptions. Therefore, we can affirm that historical regularities exist within the individual regions (countries), during a certain historical period and depend on their social institutions. Attempts to find historical regularities at the human actions level (e.g. historical heroes' actions) are doomed to failure, since each act is individual. People do things under the influence of both innate and acquired properties of their nervous system, the education received and the specific social situations impact. The situation where all the conditions would repeat is impossible [12].

Regions. At the turn of $\mathrm{XX}-\mathrm{XXI}$ centuries the importance of studying the regional historical processes turned out to be so high that the study of regions substantially pressed the nationalities research. There was a steady interest in understanding the reasons of integrating local communities into broader territorial complexes with not only economic and social systems commonality, but also with a cultural one. And this is while the regional history "has still not reached the age of sub-discipline" [13].

There is no unified vision of the concept "region" in science. For some scientists, the "region" is a territory, for others - economic community, for the third - cultural and civilizational space, for the fourth — social structure community, administrative-territorial organization [14]. Summarizing different approaches, the definition could be as follows: the region is a group of countries with approximately the same institutions and moving in approximately the same direction (the Middle East, SouthEast Asia, the Caribbean, etc.) [15].

Each region development mechanism is specific, therefore, the theory, built on a region's own local history analysis, can also explain its development. A classic illustration of regional approach to world history is the work of Arnold J. Toynbee. World history, in his understanding, 
was the sum of 21 civilizations developing according to their specific canons. Incomprehension of the regions specific character leads to serious political costs. From the erroneous use of sociocultural criteria of one society in relation to another, follows a whole complex of unreasonable claims and phobias of some peoples towards others [16].

Periods. Each region is experiencing certain development stages or historical periods. For example, in the history of Russia there were five periods - Ancient Russia, Specific Russia, Moscow Russia, the Russian Empire, and Soviet Russia. In the history of the West there exist its own periods, in the history of China - its own, etc. Following this principle - the regions and periods analysis - the academic historical institutions structure was formed. Of course, we cannot make the period's significance absolute, and it is wrong to concentrate only on the region.

Only integrated approach to space-time allows us to achieve the integrity in the historical shifts perception.

These shifts manifest themselves at the institutions level.

Institutions. They represent stable, once-formed and continuing traditions in the field of politics, economic and social relations, in the spiritual sphere [16]. Each period has its own institutions. Their transformation can be the basis for changing the content of the period, the society transition to a different state. For example, during the period of Moscow Russia, a monarchy represented political institutions in a caste-representative form, Zemsky Sobor, Boyar Duma, and the Church. Studying historical regularities through the social institutions evolution is much more logical and effective. For their time these institutions were quite effective. However, already at the beginning of the next imperial period they were not.

A problem arises: socio-political institutions change in the course of revolutions, but how long do people's habits, people's traditions, political mentality last? [17, 18] Back in 1960, H. Daiker and H. Frieda stated: "the observation that the peoples are different is a common place. However, without an answer, the question remains: are these differences truly national differences, that is, characteristics of the nationality as a whole? Are these characteristics specific to the nation, that is, do they vary from one nation to another?" [19]. It is possible that the mentality as a collective-personal entity, especially the ethnos culture, is a stable spiritual value, deep attitudes. However, politics depends not so much on the national traditions as on the political views. Based on the historical experience of the XX century we can argue that political mentality is a reaction of one or two generations to economic and socio-political realities [20].

\section{CONCLUSION}

History interaction with natural and social sciences played an important role in understanding history as a science, which contributed to the new methods and historical research emergence, the new possibilities for information processing, for example, counterfactual modeling [21]. Polyphony in the ways of searching and processing information is one of the ways of approaching the truth. Historians who deal with historical regularities identification can do this, primarily at the level of regions, periods and social institutions. At the human actions level, regularities are much more difficult to see, since the subjective and random factors influence is very great here.

\section{REFERENCES}

[1] Anisimov A.M. What is science? RUDN Journal of Philosophy, 2011 no. 3, pp. 121-122.

[2] Abdullin A.R, Rakhmatullin R.Yu. History and philosophy of science. A handbook for post-graduate students. Ufa, Oriental University Publ., 2007.

[3] Leyman I.I. Science as a social institution, Leningrad, Nauka Publ., 1971.

[4] Feynman R., Leighton R., Sands M. Feynman lectures on physics, vol. 1-2, Moscow, 1976.

[5] Anisimov A.M. opere citato

[6] Lebedev S.A. The Reassembly of the Epistemology // Voprosy filosofii. 2015. № 6. P. 53-64 .

[7] Panfilova T.V. The problem of historical regularity, Social Studies, 2002, no. 4 (29), pp. 5-19.

[8] Gerasimov O.V. Scientific knowledge of historical knowledge and historical theories: epistemological and methodological aspects Vestnik of Volzhsky University after V.N. Tatishchev, 2014, no. 1 (15), pp. 29-35.

[9] Starostenkov N.V. Problems of theory and methodology of historical science. RSSU Proceedings. Social Philosophy, History and Political Science, Moscow State University Publ., 2010, no. 5, pp. 54-60.

[10] Komissarov I; Nekhamkin V. The Models of Historical Cognition: Current Status and Prospects of Development // Istoriya-Elektronnyi nauchno-obrazovatelnyu zhurnal. 2017. Vol. 8. Issue 2. DOI: 10.18254/S0001779-5-1

[11] Medushevsky A.N. Strict and exact science. Otechestvennaya istoriya (Russian History), 2011, no. 11, p. 32.

[12] Zemtsov.B.N., Suzdaleva T.R. Epistemological determinations of historical research. Proc. of the XLIII International Research and Practice Conference and the 1st stage of the Championship in the historical and philosophical sciences. London, February 18-22, 2013, ed. Pavlov V., pp. 35-36.

[13] An Agenda for Regional History, ed. B. Lancaster, D. Newton, N Vall, Newcastle-upon-Tyne, 2007. p. VIII.

[14] Repina L.P. Theoretical grounds and prospects of regional history Prepodavatel XXI vek, 2013, no. 3, p. 131.

[15] Suzdaleva T.R. Migratory processes in the context of geopolitics // Vestnik Tomskogo gosudarstvennogo universiteta-Filosofiyasotsiologiya-politologiya-Tomsk state university journal of philosophy sociology and political science. 2016. № 3 (36). P. 237 244. DOI: $10.17223 / 1998863 \mathrm{X} / 35 / 25$

[16] Zemtsov B.N. History of Russia in the perception of Western Europeans. Humanities Bulletin of BMSTU, 2016, no. 12 (50).

[17] Zemtsov B.N. Discussion about the Essence of the Proletarian State in the CPSU between 1919 and 1923 // Izvestia Ural Federal University Journal. Series 2. Humanities and Arts. 2016. Vol. 151. № 18 (2). P. 57-68.

[18] Gubanov N.I., Gubanov N.N. The role of mentality in the development of society: sociocultural hypothesis // Vestnik slavianskikh kultur-bulletin of slavic cultures-scientific and informational journal. 2017. Vol. 43. № 1. P. 38-51.

[19] Duijker H.C., Frijda N.H. National Character and National Stereotypes, Confluence, Amsterdam, North-Holl Publishing Company, 1960, 238 p. 
[20] Zemtsov B.N. Right as World Outlook Value of the Power (XX Century) // Tomsk State university journal of history. 2014. № 4 (30). P. 28-34.

[21] Nekhamkin V.A. A counterfactual Challenge of the Past: Ways of Negotiation // Herald of the Russian Academy of Sciences. 2017. Vol 87. Issue 2. P. 191-198. DOI: 10.1134/S1019331617020046. 